\title{
Research Paper: The Role of Index and Ring Fingers in Gender Identification and Height Estimation
}

\author{
Mitra Akhlaghi ${ }^{1,2}$, Ardeshir Sheikhazadi ${ }^{1}$, Fatemeh Khazaie ${ }^{1}$, Shima Rafiee ${ }^{1}$, Mohammad Hossein Sadeghian ${ }^{1 *}$ \\ 1. Department of Forensic Medicine, School of Medicine, Tehran University of Medical Sciences, Tehran, Iran. \\ 2. Research Center of Legal Medicine Organization, Tehran, Iran.
}

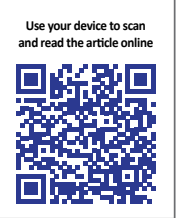

cttation: Akhlaghi M, Sheikhazadi A, Khazaie F, Sadeghian MH. The Role of Index and Ring Fingers in Gender Identification and Height Estimation. International Journal of Medical Toxicology and Forensic Medicine. 2019; 9(2):75-82. https://doi org/10.32598/ijmtfm.v9i2.24987

https://doi.org/10.32598/ijmtfm.v9i2.24987

\section{(c) 0 (3)}

Article info:

Received: 05 Nov 2018

First Revision: 28 Nov 2018

Accepted: 22 Feb 2019

Published: 01 Apr 2019

\section{Keywords:}

Gender determination, Stature, Index finger length, Ring finger length, Forensic identification

\begin{abstract}
Background: It is a challenge in forensic medicine to identify deceased bodies when body dismembered from remaining body parts, such as hands, arms, and feet. We aimed to determine gender and the correlation between stature, and index and ring fingers in an Iranian population.

Methods: In this cross-sectional study, 200 Iranian students aged between 18 and 25 years were included (2016-2017). The length of the nondominant index and ring fingers were measured from proximal crease to the tip. The exclusion criteria were a history of heavy physical work by hand, hand vocational sports, anatomical musculoskeletal deformities, and chronic internal diseases (diabetes, thyroid disorders, renal failure, etc.). The obtained data were analyzed using SPSS. t-test, Pearson's correlation coefficient, and correlation and regression models were used to analyze the achieved data.

Results: The mean height was $179 \mathrm{~cm}$ in males and $164 \mathrm{~cm}$ in females. The mean index and ring fingers lengths were $73 \mathrm{~mm}$ and $74 \mathrm{~mm}$ in males, and $68 \mathrm{~mm}$ and $68 \mathrm{~mm}$ in females, respectively. The mean sum of index and ring fingers lengths were $147 \mathrm{~mm}$ in males and $136 \mathrm{~mm}$ in females. Height, index and ring fingers length, and the sum of them significantly differed between genders $(\mathrm{P}<0.0001)$. The accuracy of gender determination was $92 \%, 71 \%$, $73 \%$ and $74.5 \%$ in terms of stature, index finger length, ring finger length, and the sum of index and ring fingers length, respectively. The correlation between height and index finger length, as well as the height and ring finger length, were significant in males, females, and total cases $(\mathrm{P}<0.0001)$.
\end{abstract}

Conclusion: Based on this study, index and ring fingers lengths can be used to predict height and determine gender.

* Corresponding Author:

Mohammad Hossein Sadeghian, MD.

Address: Department of Forensic Medicine, School of Medicine, Tehran University of Medical Sciences, Tehran, Iran.

Tel: +98 (21) 66405588

E-mail: mhsadeghian@sina.tums.ac.ir 


\section{Introduction}

$\Lambda$

primary aim of forensic medicine is the identification of persons [1-5]. Stature as an identification factor is a quantitative racial characteristic affected by factors such as nutrition, environment, gender, and genetics [6-9]. Stature is higher in males; previous studies revealed a correlation between $Y$ chromosome and stature [10]. Bone epiphysis fusion occurs later in males and they have two more years of bone growth, in comparison to females $[9,11]$.

Stature estimation using long bones is more preferable, reliable and accurate, as its' correlation coefficient is higher $[1,5]$. However, in conditions that the body is being dismembered, it is important to identify a deceased person from remaining body parts, such as head, hands, arms, and feet [6-8]. Therefore, it is necessary to estimate stature from body parts in various populations and to narrow possible victim matches $[5,12]$.

Akhlaghi et al. reported a significant relationship between the dimensions of upper limb length and the stature of 100 Iranian students aged between 21 and 26 years. They also investigated a regression formula to estimate stature which can be useful in anthropometry [9]. Kim et al. evaluated stature estimation from hand and foot dimensions in a Korean population and reported that stature was larger in males [7].

Bardale et al. estimated stature using index and ring fingers lengths in 195 adult students aged between 19 and 26 years [1]. Krishan et al. explored the correlation between stature, and index and ring fingers lengths in 140 North Indian adolescents [5]. Sen et al. aimed to measure regression model accuracy between stature and index and ring fingers lengths among North Eastern Indians aged between 18 and 60 years [13].

Previous studies revealed a significant correlation between stature and fingers length. Various research studies estimated the stature from the remaining finger bones. However, studies on stature estimation using index and ring fingers in the Iranian population are scarce. Therefore, we aimed to determine the correlation between stature and index and ring fingers in the Iranian population.

\section{Participants and Methods}

In this cross-sectional study, 200 Iranian students (100 males and 100 females) from Tehran University of medical sciences aged 18-25 years were investigated (2016-
2017). This study was approved by the Institutional Review Board of Tehran University of Medical Sciences (code: IR.TUMS.MEDICINE.REC.1395.1194). Exclusion criteria were a history of heavy physical work by hand, hand vocational sports, anatomical musculoskeletal deformities, and chronic internal diseases (diabetes, thyroid disorders, renal failure, etc.). After providing a brief explanation about the study, written consent forms were obtained from all samples. Data about gender, age, stature, and the length of index and ring fingers were collected.

The samples' height was measured from vertex to heel in a standing position (barefoot, buttock and heels touching the wall). Stature was measured by a tape measure with an accuracy of a centimeter. The length of the nondominant index and ring fingers was measured from proximal crease to the tip. The fingers length was measured by a caliper with an accuracy of millimeters.

The obtained data were analyzed using SPSS. The age, height, and index and ring fingers length were reported as Mean \pm SD. T-test, Pearson's correlation coefficient, and regression models were used to analyze and explore relationships between the studied parameters. $\mathrm{P}<0.05$ was considered as statistically significant.

\section{Results}

The Mean \pm SD age of study samples was $21.83 \pm 1.83$ years. There was no significant difference between the mean age of the two genders $(\mathrm{P}>0.05)$. According to Table 1, the Mean \pm SD height was $171.55 \pm 9.69 \mathrm{~cm}$ in total cases, $179.05 \pm 6.87 \mathrm{~cm}$ in males, and $164.04 \pm 5.27$ $\mathrm{cm}$ in females, which differed significantly $(\mathrm{P}<0.0001)$. The Mean \pm SD lengths of index and ring fingers were $70.46 \pm 5.18 \mathrm{~mm}$ and $70.93 \pm 5.39 \mathrm{~mm}$ in total samples, $73.15 \pm 4.82 \mathrm{~mm}$ and $73.68 \pm 4.66 \mathrm{~mm}$ in males, and $67.78 \pm 4.03 \mathrm{~mm}$ and $68.18 \pm 4.63 \mathrm{~mm}$ in females, respectively. There was a statistically significant difference between genders in the length of the index and ring fingers $(\mathrm{P}<0.0001)$. The Mean \pm SD sum of index and ring fingers were $146-83 \pm 8.91 \mathrm{~mm}$ in males and $135.96 \pm 8.19$ $\mathrm{mm}$ in females; there was a significant difference between genders in this variable $(\mathrm{P}<0.0001)$.

According to the observed statistically, significant differences, Receiver Operating Characteristic (ROC) curves were drawn to assess the precision of each variable for gender determination in demarking point. The Area Under the Curve (AUC) for ROC curves are presented in Figure 1. Using ROC curves, we identified distinction points for each measured characteristic. Dis- 
Table 1. The descriptive statistics

\begin{tabular}{|c|c|c|c|c|c|c|c|}
\hline \multirow[b]{2}{*}{ Gender } & \multirow[b]{2}{*}{ Parameter } & \multirow[b]{2}{*}{ Mean $\pm S D$} & \multirow[b]{2}{*}{ Min. } & \multirow[b]{2}{*}{ Max. } & \multicolumn{2}{|c|}{ 95\% Confidence Interval } & \multirow[b]{2}{*}{$\mathbf{P}$} \\
\hline & & & & & $\begin{array}{l}\text { Lower } \\
\text { bound }\end{array}$ & Upper bound & \\
\hline \multirow{5}{*}{ Male } & Age & $21.58 \pm 1.97$ & 18 & 25 & 21.19 & 21.97 & 0.058 \\
\hline & Height* & $179.05 \pm 6.87$ & 157 & 197 & 177.69 & 180.48 & $<0.0001^{* * *}$ \\
\hline & Index finger length** & $73.15 \pm 4.82$ & 61 & 89 & 72.19 & 74.11 & $<0.0001 * * *$ \\
\hline & Ring finger length** & $73.68 \pm 4.66$ & 60 & 90 & 72.75 & 74.61 & $<0.0001^{* * *}$ \\
\hline & Index+ring fingers length** & $146.83 \pm 8.91$ & 124 & 179 & 145.06 & 148.60 & $<0.0001^{* * *}$ \\
\hline \multirow{5}{*}{ Female } & Age & $22.07 \pm 1.65$ & 19 & 25 & 21.74 & 22.40 & 0.058 \\
\hline & Height * & $164.04 \pm 5.27$ & 152 & 180 & 162.99 & $165-09$ & $<0.0001^{* * *}$ \\
\hline & Index finger length** & $67.78 \pm 4.03$ & 58 & 80 & 66.98 & 68.58 & $<0.0001^{* * *}$ \\
\hline & Ring finger length** & $68.18 \pm 4.63$ & 57 & 79 & 67.26 & 69.10 & $<0.0001^{* * *}$ \\
\hline & Index+ring fingers length** & $135.96 \pm 8.19$ & 117 & 158 & 134.33 & 137.59 & $<0.0001^{* * *}$ \\
\hline \multirow{5}{*}{ Total } & Age & $21.83 \pm 1.83$ & 18 & 25 & 21.57 & 22.08 & 0.058 \\
\hline & Height* & $171.55 \pm 9.69$ & 152 & 197 & 170.19 & 172.90 & $<0.0001^{* * *}$ \\
\hline & Index finger length ** & $70.46 \pm 5.18$ & 58 & 89 & 69.74 & 71.19 & $<0.0001^{* * *}$ \\
\hline & Ring finger length** & $70.93 \pm 5.39$ & 57 & 90 & 70.18 & 71.68 & $<0.0001^{* * *}$ \\
\hline & Index+ring fingers length** & $141.40 \pm 10.12$ & 117 & 179 & 139.98 & 142.81 & $<0.0001^{* * *}$ \\
\hline
\end{tabular}

${ }^{*}$ Centimeter; ${ }^{* *}$ Millimeter; ${ }^{* * *} \mathrm{P}<0.05$ is considered as statistically significant.

tinction points were $169.5 \mathrm{~cm}$ for stature, $69.5 \mathrm{~mm}$ for the index finger, $70.5 \mathrm{~mm}$ for the ring finger, and 140.5 $\mathrm{mm}$ for the sum of index and ring fingers.

Accuracy of gender determination was $92 \%, 71 \%$, $73 \%$, and $74.5 \%$ in terms of stature, index finger length, ring finger length, and the sum of index and ring fingers length, respectively (Table 2).
Based on Table 3, Person's correlation coefficients of height and index finger length were $0.66,0.53$, and 0.41 in total, male, and female samples, respectively. Moreover, Person's correlation coefficients of height and ring finger length were $0.69,0.56$, and 0.52 in total, male and female samples, respectively. Person's correlation coefficient in the total sample population was $0.66,0.69$, and 0.71 in the index finger, ring finger, and height, respectively. The correlation between height, and index

Table 2. Accuracy of height, index finger length, ring finger length in demarking point

\begin{tabular}{|c|c|c|c|c|c|c|}
\hline Gender determination parameter & D. Point $* * *$ & $\begin{array}{c}\text { Sensitivity } \\
\text { (\%) }\end{array}$ & $\begin{array}{c}\text { Specificity } \\
\text { (\%) }\end{array}$ & $\operatorname{PPV}(\%)^{* * * *}$ & $\operatorname{NPV}(\%) * * * * *$ & Accuracy(\%) \\
\hline Height* & 169.5 & 95 & 89 & 89.6 & 94.7 & 92 \\
\hline Index finger length** & 69.5 & 74 & 68 & 69.8 & 72.3 & 71 \\
\hline Ring finger length** & 70.5 & 75 & 71 & 72.1 & 74 & 73 \\
\hline Index+ring finger length** & 140.5 & 76 & 73 & 73.8 & 75.3 & 74.5 \\
\hline
\end{tabular}

${ }^{*}$ Centimeter; ${ }^{* *}$ Millimeter; ${ }^{* *}$ Demarking points; ${ }^{* * * *}$ Positive predictive value; ${ }^{* * * * *}$ Negative predictive value. 
Table 3. Correlation between stature and index finger length and ring finger length in male, female and total samples

\begin{tabular}{|c|c|c|c|c|}
\hline Gender & Parameter & Person's Correlation Coefficient ( $r$ ) & SEE $(\mathrm{cm})$ & P* \\
\hline \multirow[b]{2}{*}{ Male } & Index finger length & 0.53 & 5.85 & $<0.0001$ \\
\hline & Ring finger length & 0.56 & 5.68 & $<0.0001$ \\
\hline \multirow{2}{*}{ Female } & Index finger length & 0.41 & 4.81 & $<0.0001$ \\
\hline & Ring finger length & 0.52 & 4.51 & $<0.0001$ \\
\hline \multirow{3}{*}{ Total } & Index finger length & 0.66 & 7.25 & $<0.0001$ \\
\hline & Ring finger length & 0.69 & 7.01 & $<0.0001$ \\
\hline & Index+ring finger length & 0.71 & 6.85 & $<0.0001$ \\
\hline
\end{tabular}

Table 4. Area under ROC curve in parameters

\begin{tabular}{ccccc}
\hline Parameter & Area & $\mathbf{P}$ & \multicolumn{2}{c}{ \%95 Confidence Interval } \\
\cline { 4 - 5 } & & & Lower Bound & Upper Bound \\
\hline Height & 0.97 & $<0.0001$ & 0.92 & 0.98 \\
Index finger & 0.80 & $<0.0001$ & 0.74 & 0.86 \\
\hline Ring finger & 0.80 & $<0.0001$ & 0.73 & 0.86 \\
\hline Index+ ring fingers & 0.82 & $<0.0001$ & 0.76 & 0.88 \\
\hline * & & & International Journal of \\
\hline
\end{tabular}

${ }^{*} \mathrm{P}<0.05$ is considered as statistically significant.

and ring fingers length in male, female and total cases was significant $(\mathrm{P}<0.0001)$. On the basis of statistically significant correlation between height, and index and ring fingers length, the following formulas were estimated:

Height $(\mathrm{cm})=(1.24 \times$ length of index finger $[\mathrm{mm}])+$ 83.916

Height of male $(\mathrm{cm})=(0.759 \times$ length of index finger $[\mathrm{mm}])+123.530$

Height of female $(\mathrm{cm})=(0.548 \times$ length of index finger $[\mathrm{mm}])+126.902$

Height $(\mathrm{cm})=(1.104 \times$ length $\quad$ of ring finger $[\mathrm{mm}])+93.329$

Height of male $(\mathrm{cm})=(0.838 \times$ length of ring finger $[\mathrm{mm}])+117.26$

Height of female $(\mathrm{cm})=(0.597 \times$ length of ring finger $[\mathrm{mm}])+123.33$
Height $(\mathrm{cm})=(0.807 \times$ length $\quad$ of ring finger $[\mathrm{mm}])+(0.546 \times$ length of index finger $[\mathrm{mm}])+75.81$

\section{Discussion}

We investigated the correlation between stature, and index and ring fingers length, as well as the correlation between stature and gender in an Iranian population. The average height was $171.55 \mathrm{~cm}$ in the total subjects, $179.05 \mathrm{~cm}$ in males and 164.04 in females, which was statistically significant $(\mathrm{P}<0.05)$. Akhlaghi et al. reported the average height of 100 Iranian students aged between 21 and 26 years as $176 \mathrm{~cm}$ in males and 162 $\mathrm{cm}$ in females [9].

Oladipo et al. stated that the average height was 171.53 $\mathrm{cm}$ in males and $161.81 \mathrm{~cm}$ in females among $500 \mathrm{Ni}-$ gerians aged between 18 and 77 years [6]. Furthermore, Danborno et al. reported that the average height in 1082 Nigerians was $173.31 \mathrm{~cm}$ in males and $161.62 \mathrm{~cm}$ in females [14]. Therefore, the obtained results regarding the average height and the significant difference between male and female samples were in line with the previous 
Table 5. The comparison of stature, and index and ring fingers in genders between our study and previous reports

\begin{tabular}{|c|c|c|c|c|c|c|c|c|c|}
\hline \multirow{3}{*}{ Study } & \multirow{3}{*}{ Methods } & \multirow{3}{*}{ Nationality } & \multirow{3}{*}{ Gender } & \multicolumn{6}{|c|}{ Results } \\
\hline & & & & \multirow{2}{*}{ Height * } & \multirow{2}{*}{ Index F. ** } & \multirow{2}{*}{ Ring F. ** } & \multicolumn{2}{|c|}{ P. C } & \multirow{2}{*}{$\mathbf{P} * * *$} \\
\hline & & & & & & & IF & RF & \\
\hline \multirow{2}{*}{$\begin{array}{l}\text { Akhlaghi et } \\
\text { al. [9] }\end{array}$} & \multirow{2}{*}{ Direct } & \multirow{2}{*}{ Iranian } & Male & 176 & 62 & 80 & 0.66 & 0.48 & $<0.05$ \\
\hline & & & Female & 162 & 60 & 75 & 0.43 & 0.58 & $<0.05$ \\
\hline \multirow{2}{*}{$\begin{array}{l}\text { Bardale et } \\
\text { al. [1] }\end{array}$} & \multirow{2}{*}{ Direct } & \multirow{2}{*}{ Indian } & Male & 171 & 74 & 77 & 0.51 & 0.54 & $<0.05$ \\
\hline & & & Female & 157 & 68 & 69 & 0.61 & 0.59 & $<0.05$ \\
\hline \multirow{2}{*}{$\begin{array}{l}\text { Danborno } \\
\text { et al. [14] }\end{array}$} & \multirow{2}{*}{ Direct } & \multirow{2}{*}{ Nigerian } & Male & 173 & 74 & 78 & 0.39 & 0.50 & $<0.05$ \\
\hline & & & Female & 162 & 70 & 72 & 0.40 & 0.41 & $<0.05$ \\
\hline \multirow{2}{*}{$\begin{array}{c}\text { Ibrahim MA } \\
\text { et al. [17] }\end{array}$} & \multirow{2}{*}{ Direct } & \multirow{2}{*}{ Saudi Arabia } & Male & 175 & 75 & 78 & 0.54 & 0.44 & $<0.05$ \\
\hline & & & Female & 159 & 69 & 68 & 0.61 & 0.56 & $<0.05$ \\
\hline \multirow{2}{*}{$\begin{array}{c}\text { Jee et al. } \\
\text { [18] }\end{array}$} & \multirow{2}{*}{ Direct } & \multirow{2}{*}{ Korean } & Male & 170 & 70 & 74 & 0.50 & 0.49 & $<0.05$ \\
\hline & & & Female & 156 & 69 & 66 & 0.42 & 0.47 & $<0.05$ \\
\hline \multirow{2}{*}{$\begin{array}{l}\text { Krishan et } \\
\text { al. [5] }\end{array}$} & \multirow{2}{*}{ Direct } & \multirow{2}{*}{ Indian } & Male & 162 & 67 & 72 & 0.71 & 0.67 & $<0.05$ \\
\hline & & & Female & 153 & 65 & 67 & 0.53 & 0.45 & $<0.05$ \\
\hline \multirow{2}{*}{$\begin{array}{l}\text { Oladipo et } \\
\text { al. [6] }\end{array}$} & \multirow{2}{*}{ Direct } & \multirow{2}{*}{ Nigerian } & Male & 172 & 71 & 74 & 0.51 & 0.51 & $<0.05$ \\
\hline & & & Female & 162 & 67 & 70 & 0.34 & 0.33 & $<0.05$ \\
\hline \multirow{3}{*}{ This study } & \multirow{3}{*}{ Direct } & \multirow{3}{*}{ Iranian } & Male & 179 & 73 & 74 & 0.53 & 0.56 & $<0.05$ \\
\hline & & & & & & & & & \\
\hline & & & Female & 164 & 68 & 68 & 0.41 & 0.52 & $<0.05$ \\
\hline
\end{tabular}

studies. The mean length of the index finger in this study was $73.15 \mathrm{~mm}$ in males and $67.78 \mathrm{~mm}$ in females, which was statistically significant $(\mathrm{P}<0.05)$. The mean length of the index finger in males was similar to the results of Bardale et al. and Danborno and colleagues [1, 14]. Similar results have been obtained in terms of the mean length of the index finger in females by Bardale et al. [1]. However, the mean length of the index finger in male and female samples was lower in the studies by Akhlaghi et al. and Krishan and associates [5, 9].

In this study, the mean length of the ring finger was $73.68 \mathrm{~mm}$ in males and $68.18 \mathrm{~mm}$ in females, which was statistically significant $(\mathrm{P}<0.05)$. The mean length of the ring finger in males was similar to the results of Krishan et al. but lower than those of Danborno et al. Bardale et al. and Akhlaghi et al. [1, 5, 9, 14]. The obtained results on the mean length of index finger in females were in line with the studies by Krishan et al. Bardale et al. and Sen et al. but lower than those of Dan- borno et al. and Akhlaghi et al. [1, 5, 9, 13, 14]. Based on the results obtained from our assay and previous studies, the mean length of index and ring fingers were significantly higher in males $(\mathrm{P}<0.05)[1,5,13-15]$.

Suseelamma et al. Oladipo et al. and Krishan et al. suggested a significant correlation between height and index finger length, which was higher among males than females $[5,6,15]$. Previous studies demonstrated similar results regarding the significant correlation between average ring finger length and height $[1,5,6$, 13-16]. Pearson's correlation coefficient between index and ring fingers length and height was higher in males than females $(\mathrm{P}<0.05)$, which was similar to the results of Krishan et al. [5].

Inconsistent with our results, Bardale et al. reported a higher correlation between height, and index and ring fingers length in females [1]. Our obtained data indicated 0.66 , and 0.60 correlation coefficients between index 


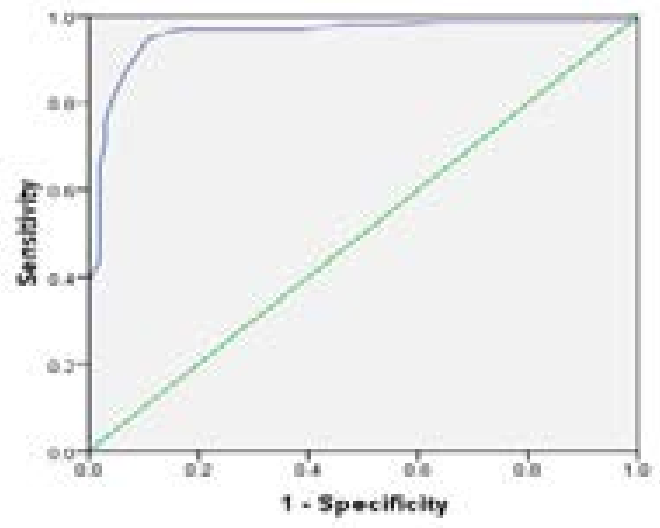

Height

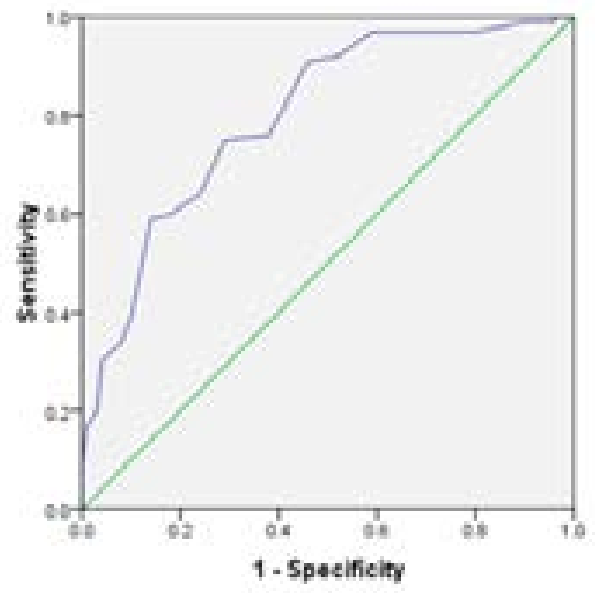

Ring finger

Figure 1. The ROC curve of all criteria

finger length and height, and between ring finger length and height, respectively. Results obtained by Oladipo et al. was in line with ours [6]. On the other hand, Krishan et al. Tyagi et al. and Sen et al. reported that index finger length had a higher correlation coefficient to estimate height, in comparison to the ring finger length $[5,13$, 16]. The Area Under the Curve (AUC) for ROC curves are presented in Table 4 . Table 5 presents a comparison of stature and index and ring fingers in genders between our study and previous reports.

Based on the obtained results, the average sum of the index and ring fingers length significantly differed between males and females $(\mathrm{P}<0.05)$. The correlation between the sum of index and ring fingers length and height was equal to 0.71 , which is higher than the length of index or ring fingers, alone. However, studies disregarded gender determination and height estimation according to the sum of index and ring fingers length.
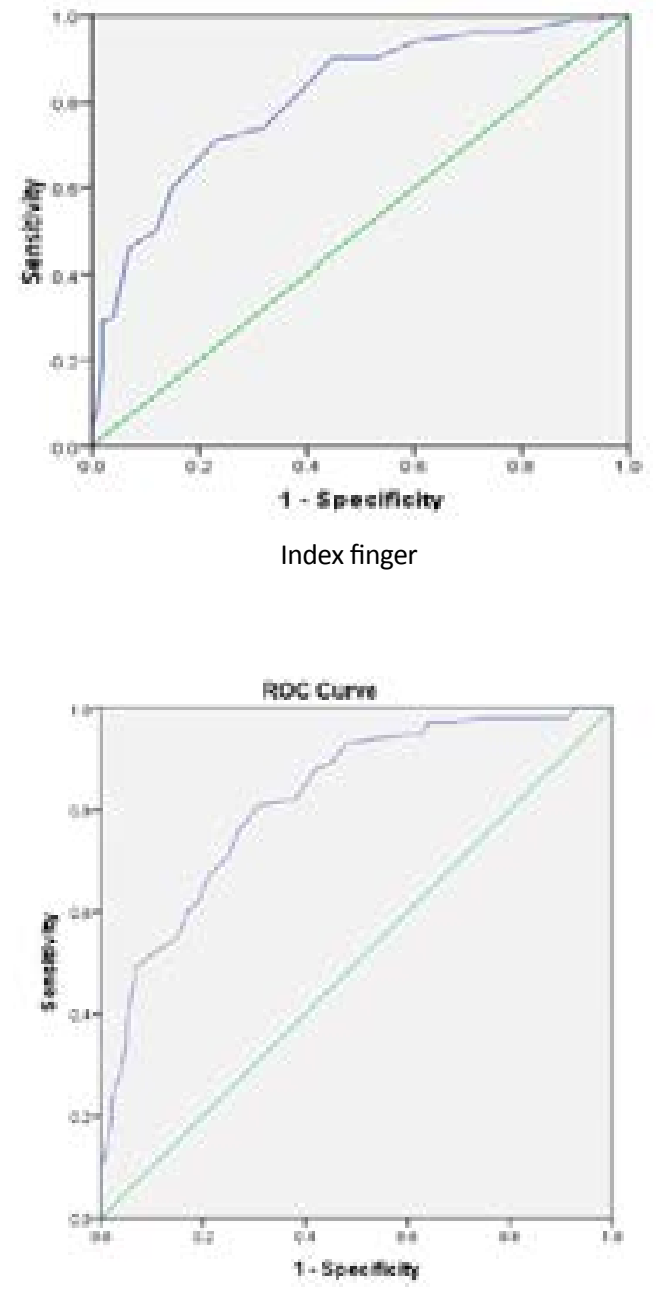

Index+ring fingers

International Journal of Medical Toxicology \& forensic Medicine

\section{Conclusion}

There are various anthropometric criteria to determine gender with different accuracy levels. In addition, the accuracy of these criteria varies in different races that highlight the need for racial anthropologic studies. Therefore, we determined the accuracy of height and index and ring fingers lengths in gender determination. Index and ring fingers lengths can be used to predict height and determine gender. The highest and lowest accuracy levels belonged to the height (92\%) and index finger length (71\%), respectively.

\section{Ethical Considerations}

\section{Compliance with ethical guidelines}

All ethical principles were considered in this article. The participants were informed about the purpose of the 
research and its implementation stages; they were also assured about the confidentiality of their information; moreover, they were allowed to leave the study whenever they wish, and if desired, the results of the research would be available to them.

\section{Funding}

This study was approved by the Institutional Review Board of Tehran University of Medical Sciences (code: IR.TUMS.MEDICINE.REC.1395.1194).

\section{Authors' contributions}

All authors contributed in preparing this article.

\section{Conflict of interest}

The authors declared no conflict of interest.

\section{References}

[1] Bardale RV, Dahodwala TM, Sonar VD. Estimation of stature from index and ring finger length. Journal of Indian Academy of Forensic Medicine. 2013; 35(4):353-57.

[2] Paulis MG. Estimation of stature from handprint dimensions in Egyptian population. Journal of forensic and legal medicine. 2015; 34:55-61. [DOI:10.1016/j.jflm.2015.05.007] [PMID]

[3] Agnihotri AK, Tangman Y. Estimating Stature from the Measurements of Upper Limbs in the Indo-Mauritian Population. Journal of Forensic Identification. 2018; 68(2):234-55. [DOI:10.4103/sjfms.sjfms_10_17]

[4] Gupta S, Gupta V, Tyagi N. Index/ring finger ratio, hand and foot index: Gender estimation tools. Journal of Clinical and Diagnostic Research. 2017; 11(6):ZC73. [DOI:10.7860/ JCDR/2017/25807.10084]

[5] Krishan K, Kanchan T, Asha N. Estimation of stature from index and ring finger length in a North Indian adolescent population. Journal of Forensic and Legal Medicine. 2012; 19(5):285-90. [DOI:10.1016/j.jflm.2011.12.036]

[6] Oladipo G, Ezi G, Okoh P, Abidoye AO. Index and ring finger lengths and their correlation with stature in a Nigerian population. Annals of Bioanthropology. 2015; 3(1):18-21. [DOI:10.4103/2315-7992.160742]

[7] Kim W, Kim YM, Yun MH. Estimation of stature from hand and foot dimensions in a Korean population. Journal of Forensic and Legal Medicine. 2018; 55:87-92. [DOI:10.1016/j. jflm.2018.02.011] [PMID]

[8] Katwal B, Panta P, Pandit R, Shrestha N. Estimation of stature from length of middle finger among Nepalese medical student of Nepal Medical College and Teaching Hospital. MedPulse International Journal of Forensic Medicine. 2017; 3(2):1-4. [DOI:10.26611/1018311]
[9] Akhlaghi M, Hajibeygi M, Zamani N, Moradi B. Estimation of stature from upper limb anthropometry in Iranian population. Journal of Forensic and Legal Medicine. 2012; 19(5):2804. [DOI:10.1016/j.jflm.2011.12.034]

[10] Yamada K, Ohta M, Yoshimura K, Hasekura H. A possible association of $\mathrm{Y}$ chromosome heterochromatin with stature. Human Genetics. 1981; 58(3):268-70. [DOI:10.1007/ BF00294920]

[11] Cutler GB Jr. The role of Estrogen in bone growth and maturation during childhood and adolescence. The Journal of Steroid Biochemistry and Molecular Biology. 1997; 61(36):141-4. [DOI:10.1016/S0960-0760(97)80005-2]

[12] Zulkifly NR, Wahab RA, Layang E, Ismail D, Desa WNSM, Hisham S, et al. Estimation of stature from hand and handprint measurements in Iban population in Sarawak, Malaysia and its applications in forensic investigation. Journal of Forensic and Legal Medicine. 2018; 53:35-45. [DOI:10.1016/j jflm.2017.10.011] [PMID]

[13] Sen J, Kanchan T, Ghosh A, Mondal N, Krishan K. Estimation of stature from lengths of index and ring fingers in a North-eastern Indian population. Journal of Forensic and Legal Medicine. 2014; 22:10-5. [DOI:10.1016/j.jflm.2013.11.010]

[14] Danborno B, Adebisi S, Adelaiye A, Ojo S. Estimation of height and weight from the lengths of second and fourth digits in Nigerians. The Internet Journal of Forensic Science. 2009; 3(2):1-6. [DOI:10.5580/1133]

[15] Suseelamma D, Gayathri P, Deepthi S, Chandra MM, Uday $\mathrm{K}$, Amarnath M. Study of correlation between stature and length of fingers. Scholars Journal of Applied Medical Sciences. 2014; 2(2D):773-84.

[16] Tyagi AK, Kohli K, Verma SK, Aggarwal BBL. Correlation between stature and fingers length. International Journal of Medical Toxicology and Legal Medicine 1999; 1(2):20-22.

[17] Ibrahim MA, Khalifa AM, Hassan HA, Tamam HG, Hagras AM. Estimation of stature from hand dimensions in North Saudi population, medicolegal view. The Saudi Journal of Forensic Medicine and Sciences. 2018; 1(1):19-27. [DOI:10.4103/sjfms.sjfms_10_17]

[18] Jee SC, Yun MH. Estimation of stature from diversified hand anthropometric dimensions from Korean population. Journal of Forensic and Legal Medicine. 2015; 35:9-14. [DOI:10.1016/j.jflm.2015.06.014] [PMID] 
This Page Intentionally Left Blank 